justify an estimation of the excess risk, the results suggest that antithyroid drugs may cause aplastic anaemia but also that the excess risk associated with their use is very low.

This study was sponsored by Hoechst AG, Frankfurt, Federal Republic of Germany. Partial support was also provided by the governments of Hungary and Bulgaria and by the Corporation of Swedish Pharmacies. The study is supervised by an honorary international advisory board, whose members are Sir Richard Doll (Oxford), Per Knut M Lunde (Oslo), and Sven Moeschlin (Solothurn); it would not have been possible without the cooperation of over 300 hospitals in the participating centres.

PARTICIPANTS in the study were as follows: Chairman: M Levy, Jerusalem; Coordination and data analysis (Slone Epidemiology Unit, Boston): D Slone (deceased), S Shapiro, D W Kaufman, T Anderson, L J Blair, P T Cook, J J Farrell, L F Gaetano, J P Kelly, R Matis, C L Wells; Investigators: J R Laporte, X Carne, Barcelona; $H$ Kewitz, Berlin; G Retsagi, S Hollan, Budapest; M Levy, Z Stern, Jerusalem; G Tognoni, Milan; V Vlahov, Sofia; B E Wiholm, M Keisu, Stockholm; H Heimpel, W Heit, Ulm; Data collection: L Ibanez, Barcelona; M Klein, C Scott, Berlin; E Czink, A Laszlo, Budapest; M Beiski, F Simon, Z Toledano, Jerusalem; C LaVecchia, P Liati, M G Zurlo, Milan; N Bacracheva, Sofia; K Jacobsen, M Sandberg, Stockholm; I Bayer, R Kreuzer, Ulm; Haematology review committee: H Heimpel, W Heit, Ulm; G Lambertenghi-Deliliers, Milan; A Polliack, Jerusalem.

1 MacKenzie CG, MacKenzie JB. Effect of sulfonamides and thioureas on the thyroid gland and basal metabolism. Endocrinology 1943;32:185-209.

2 Astwood EB, Sullivan J, Bissell A, et al. Action of certain sulfonamides and of thiourea upon the function of the thyroid gland of the rat. Endocrinology 1943;32:210-25.

3 Trotter WR. The relative toxicity of antithyroid drugs. Fournal of New Drugs 1962;2:333-43.

4 Ahn YS, Yunis AA. Antithyroid therapy and leukocytes. In: Dimitrol NV, Nodine JH, eds. Drugs and hematologic reactions. New York: Grune and Stratton, 1974:249-59.

5 Rosove MH. Agranulocytosis and antithyroid drugs. West f Med 1977;126: 339-43.

6 International Agranulocytosis and Aplastic Anemia Study. The design of a study of the drug etiology of agranulocytosis and aplastic anemia. Eur $\mathcal{C}$ Clin Pharmacol 1983;24:833-6.

7 International Agranulocytosis and Aplastic Anemia Study. Risks of agranulocytosis and aplastic anemia: a first report of their relation to drug use with special reference to analgesics. $\mathcal{F} A M A 1986 ; 256: 1749-57$.

\title{
Gastrointestinal complications of dialysis related amyloidosis
}

\author{
E R Maher, S Hamilton Dutoit, R A Baillod, \\ P Sweny, J F Moorhead
}

Departments of

Nephrology and

Histopathology, Royal

Free Hospital and School

of Medicine, London

NW3 2QG

E R Maher, MRCP, registrar in

nephrology

$S$ Hamilton Dutoit,

MRCPATH, lecturer in

histopathology

R A Baillod, $\mathrm{MB}$, associate

specialist

P Sweny, FRCP, senior lecturer

in nephrology

J F Moorhead, FRCP,

consultant physician

Correspondence to:

Dr Maher, department of nephrology.
8 Guffy MM, Goeken NE, Burns CP. Granulocytotoxic antibodies in a patient with propylthiouracil-induced agranulocytosis. Arch Intern Med 1984;144: 1687-8.

9 Fibbe WE, Claas FH, Van der Star-Dijkstra W, Schaafsma MR, Meyboom $\mathrm{RH}$, Falkenburg JH. Agranulocytosis induced by propylthiouracil: evidence of a drug dependent antibody reacting with granulocytes, monocytes and haematopoietic progenitor cells. Br f Haematol 1986;64:363-73.

10 Bilezikian SB, Laleli Y, Tsan MF, et al. Immunological reactions involving leukocytes. III. Agranulocytosis induced by antithyroid drugs. fohns Hopkins Med f 1976;138:124-9.

1 Weitzman SA, Stossel TP. Drug-induced immunological neutropenia. Lancet $1978 ; \mathrm{i}: 1068-72$.

12 Armitage P. Statistical methods in medical research. New York: Wiley, 1971:380-4.

13 Miettinen OS. Proportion of disease caused or prevented by a given exposure, trait or intervention. Am f Epidemiol 1974;99:325-32.

14 Rothman KJ. Modern epidemiology. Boston: Little Brown, 1986:38-9.

15 Miettinen OS. Estimability and estimation in case referent studies. Am $\mathfrak{J}$ Epidemiol 1976;103:226-35.

16 Schlesselman JJ. Case-control studies: design, conduct, analysis. New York: Oxford University Press, 1982.

17 Shapiro S, Levy M. Metamizol: een honderdjarige treurnis. Ned Tijdschr Geneeskd 1987;131:1680-1

18 Irvine WJ, Wu FCW, Urbaniak SJ, et al. Peripheral blood leucocytes in thyrotoxicosis (Graves' disease) as studied by conventional light microscopy. Clin Exp Immunol 1977;27:216-21.

19 Cooper DS. Antithyroid drugs. N Engl J Med 1984;311:1353-62.

20 Volpe R, Karlsson FA, Jansson R, et al. Evidence that antithyroid drugs induce remissions in Graves' disease by modulating thyroid cellular activity. Clin Endocrinol (Oxf) 1986;25:453-62.

21 Totterman TH, Karlsson FA, Bengtsson M, Mendel-Hartvig I. Induction of circulating activated suppressor-like $T$ cells by methimazole therapy for Graves' disease. $N$ Engl F Med 1987;316:15-22.

22 Wall JR, Fang SL, Kuroki T, et al. In vitro immunoactivity to propylthiouracil, methimazole, and carbimazole in patients with Graves' disease: a possible methimazole, and carbimazole in patients with Graves' disease: a possible cause of antithyr $1984 ; 58: 868-72$.

23 Wiberg JJ, Nuttall FQ. Methimazole toxicity from high doses. Ann Intern Med 1972;77:414-6.

24 Arneborn P, Palmblad J. Drug-induced neutropenia: a survey for Stockholm 1973-1978. Acta Med Scand 1982;212:289-92.

25 Cooper DS, Goldminz D, Levin AA, et al. Agranulocytosis associated with antithyroid drugs. Effects of patient age and drug dose. Ann Intern Med 1983;98:26-9.

26 Heimpel H, Heit W. Drug-induced aplastic anemia: clinical aspects. Clin Hematol 1980;9:641-62.

27 Martelo OJ, Katims RB, Yunis AA. Bone marrow aplasia following propylthiouracil therapy: report of a case with complete recovery. Arch Intem Med 1967;120:587-90.

28 Edell SL, Bartuska DG. Aplastic anemia secondary to methimazole: case report and review of hematologic side effects. $\mathcal{J}$ Am Med Wom Assoc 1975;30:412-3.

29 Aksoy M, Erdem S. Aplastic anaemia after propylthiouracil. Lancet 1968;i: 1379.

30 Swanson M, Cook R. Drugs, chemicals and blood dyscrasias. Hamilton, Illinois: Drug Intelligence Publications, 1977:634.

(Accepted 28 April 1988)

return to haemodialysis four months later. Carpal tunnel decompressions were performed in 1982 and 1983 when she also suffered a spontaneous fractured neck of femur as a result of a bone cyst. In 1983 she began to complain of bilateral shoulder pains and other features of dialysis arthropathy. Two years later she was admitted with melaena. Upper gastrointestinal endoscopy showed nothing abnormal and arteriography localised the bleeding site to mid-jejunum. At laparotomy $90 \mathrm{~cm}$ of jejunum including the apparent source of bleeding was resected. After operation there was no further bleeding and the patient continued with maintenance haemodialysis. Histologically the jejunum showed no abnormality apart from extensive amyloid deposition within submucosal blood vessels.

Case 2-This patient started haemodialysis in 1972 for rapidly progressive crescentic glomerulonephritis. In 1979 she received a renal transplant but this never functioned. In 1985 bilateral carpal tunnel decompression was performed and histological examination confirmed amyloid. The next year she complained of persistent diarrhoea. Results of barium studies were not diagnostic and she continued to have diarrhoea until she died six months later from disseminated renal cell carcinoma. Necropsy showed systemic amyloid deposition (primarily in association with blood vessels) in the heart, lungs, skin, subcutaneous fat, gut, muscle, synovium, kidneys, liver, adrenal, thyroid, and lymph nodes. There was extensive deposition of amyloid throughout the 
small and large intestines affecting both vessels and lamina propria. Electron microscopy showed the characteristic features of amyloid.

\section{Comment}

The histological appearance of the amyloid (apple green birefringence under polarised light after staining with Congo red and resistance to pretreatment with potassium permanganate) in each case was consistent with dialysis related amyloidosis and not deposition of AA amyloid. In both patients immunohistology showed strong positivity of the amyloid deposits for $\beta_{2}$ microglobulin and weaker positivity for $\mathrm{P}$ component. Stains for amyloid A protein and kappa and lambda light chains were negative. Though disease of the gastrointestinal tract resulting in haemorrhage or diarrhoea is well recognised in other types of amyloidosis ${ }^{5}$ our findings represent a new aspect of dialysis related amyloidosis. This diagnosis should be considered in patients receiving long term haemodialysis who have obscure gastrointestinal disease, and it seems likely that other systemic complications of dialysis related amyloidosis will be reported.

1 Bardin T, Zingraff J, Kuntz D, Dreeke T. Dialysis-related amyloidosis. Nephrologv, Dialysis, and Transplantation 1986;1:151-4.

2 Munoz-Gomez J, Bergada-Barado E, Gomez-Perez R, Llopart-Guisan E, Subias-Sobrevia E, Sole-Arques M. Amyloid arthropathy in patients undergoing periodical haemodialysis for renal failure: a new complication. undergoing periodical haemodialys
Ann Rheum Dis 1985;44:729-33.

3 Brown EA, Arnold IR, Gower PE. Dialysis arthropathy: a complication of long term treatment with haemodialysis. Br Med f 1986;292:163-6.

4 Theaker JM, Raine AEG, Rainey AJ, Heryet A, Clark A, Oliver DO. Systemic amyloidosis of $\beta_{2}$-microglobulin type: a complication of long term haemodialysis. F Clin Pathol 1987;40:1247-51.

5 Brandt K, Cathcart ES, Cohen AS. A clinical analysis of the course and prognosis of 42 patients with amyloidosis. Am f Med 1968;44:955-69.

(Accepted I1 April 1988)

\section{Thrombocytopenia in systemic lupus erythematosus responsive to dapsone}

\section{Celia Moss, P J Hamilton}

Royal Victoria Infirmary, Newcastle upon Tyne, NE1 4LP

Celia Moss, MRCP, senior registrar in dermatology PJ Hamilton, FRCP, consultant haematologist

Correspondence to: $\mathrm{Dr}$ Moss. reported.

\section{Case report}

We report on a patient who had systemic lupus erythematosus and thrombocytopenia, which responded to treatment with dapsone. This effect of dapsone has not to our knowledge been previously

A 29 year old woman presented in 1980 with a four year history of discoid lupus erythematosus on the face. She had previously reported transient vasculitic lesions on the fingers and distal arthropathy. Investigations showed a positive test result for antinuclear factors (one in 80), low concentrations of C3 $(0.72$ (normal range 0.8-1.4) g/l) and C4 $(0.09(0 \cdot 1-0.4) \mathrm{g} / \mathrm{l}$ ), platelet count $140 \times 10^{9} / 1$, deoxyribonucleic acid binding $<20$ units/ml serum. Her skin condition was treated with dapsone $100 \mathrm{mg}$ daily for two months with an excellent response.' A year later in June 1981 her skin lesions relapsed and she was found to be thrombocytopenic (platelet count $11 \times 10^{9} / 1$ ). She had suffered a vitreous haemorrhage five months previously. Treatment with dapsone $100 \mathrm{mg}$ daily was restarted (figure), and after 10 days her platelet count had risen to $67 \times 10^{9} / 1$. She stopped taking the drug

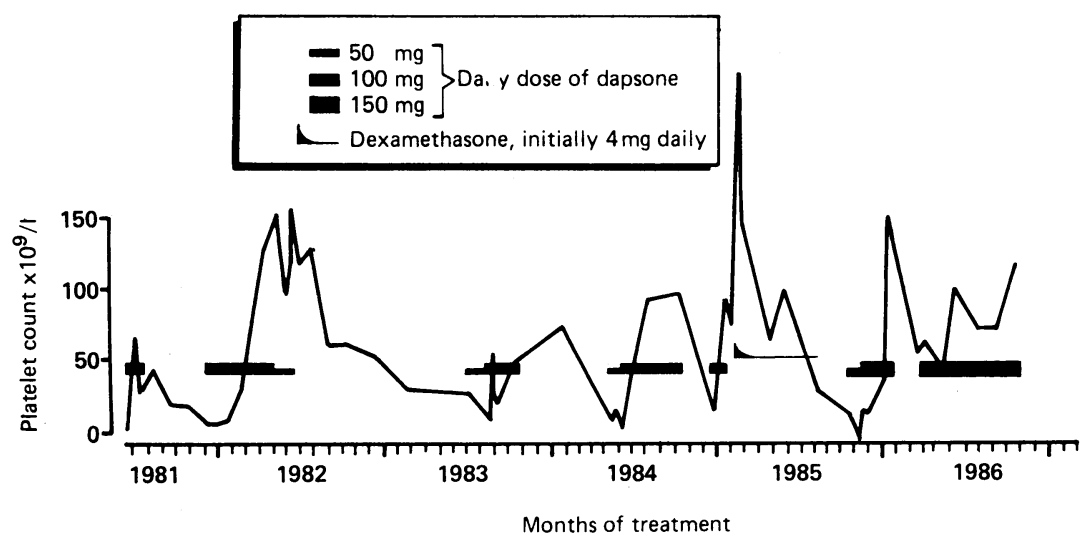

Platelet count related to treatment after two weeks because her skin had improved, and the platelet count fell progressively.

The thrombocytopenia has since persisted, associated with purpura under sites of pressure from clothing, and the discoid lesions on her face have relapsed once or twice a year. Further investigations during relapses have shown a marrow with normally maturing megakaryocytes but few platelets, platelet associated IgG ratio up to $19 \cdot 3$ (normal $<1 \cdot 6$ ), IgA $<0 \cdot 1$ (normal $0 \cdot 65-3 \cdot 0$ ) $\mathrm{g} / \mathrm{l}$, antinuclear factors up to one in 320 , and deoxyribonucleic acid binding up to 48 units $/ \mathrm{ml}$. Anti-cardiolipin antibody titres were negative. The patient has received several further courses of dapsone. A dose of $100 \mathrm{mg} /$ day reliably improves the skin and platelet count within about a month. No relation has been observed, however, between dapsone treatment and biochemical indices of disease activity. Furthermore, in January 1985, when her thrombocytopenia and discoid lesions were controlled by dapsone, her general condition worsened and she required systemic steroids to suppress her vasculitic lesions and arthropathy. In general, however, her skin and platelet problems have been successfully controlled for six years by dapsone with no side effects.

\section{Comment}

Dapsone improves several manifestations of lupus erythematosus. ${ }^{1.3}$ In a previous patient who had lupus erythematosus and urticaria that responded to dapsone concentrations of $\mathrm{CH} 50, \mathrm{C} 1$, and $\mathrm{C} 2$ returned to normal during treatment. ${ }^{2} \mathrm{Katz}$ et al have, however, disputed that dapsone affects complement. ${ }^{+}$In our patient dapsone improved discoid skin lesions and platelet count but not arthropathy, vasculitic lesions, or complement concentrations, suggesting a symptomatic rather than a central effect. Dapsone certainly affects phagocyte mediated cytotoxicity, ${ }^{5}$ which provides a possible explanation for its beneficial effects in thrombocytopenia.

1 Coburn PR, Shuster S. Dapsone and discoid lupus erythematosus. $\mathrm{Br} \mathcal{J}$ Dermatol 1982;106: 105-6.

Ruzicka T, Goerz G. Dapsone in the treatment of lupus erythematosus. $\mathrm{Br} f$ Dermatol 1981;104:53-6.

McCormack LS, Elgart ML, Turner ML. Annular subacute cutaneous lupus erythematosus responsive to dapsone. 7 Am Acad Dermatol 1984;11:397-401. Katz DI, Hertz KC, Crawford PS, Gazze LA, Frank MM, Lawley TJ. Effect of sulfones on complement deposition in dermatitis herpetiformis and on come complem.

5 Stendahl O, Molin L, Dahlgren C. The inhibition of polymorphonuclear leukocyte cytoxicity by dapsone. 7 Clin Invest 1978;62:214-20. 